\title{
Phytochemical Screening, LD50 Determination and Sub-Chronic Toxicity Studies of Methanol Seeds Extract of Nigella Sativa
}

\author{
Ahmad Shehu Muazu \\ Department of Biochemistry, Faculty of Sciences, Kano State University of Science and Technology Wudil, \\ Kano, Nigeria
}

\begin{abstract}
Nigella Sativa has long been used as a spice, food preservatives and in many countries as herbal medicine. This study was carried out to screen the Phytochemical, evaluate the $\mathrm{LD}_{50}$ and sub-chronic studies of methanol seeds extract of Nigella sativa (ASENS) in rats. Qualitative and quantitative phytochemicals were determined using standard methods. A total of twenty five rats were used for acute toxicity $\left(\mathrm{LD}_{50}\right.$, oral, rat) and sub-chronic toxicity. For the sub-chronic toxicity twelve rats were divided into four groups of three rats each. Group I served as normal control, groups II, III, IV were administered orally with ASENS at doses of 10,100 and $1000 \mathrm{mg} / \mathrm{kg}$ body weight respectively for four weeks. Phytochemical analysis revealed the presence of tannins, saponins, alkaloids and flavonoids at different concentrations with cardiac glycosides having the highest. Acute toxicity study shows no sign of toxicity or mortality up to dose of $5000 \mathrm{mg} / \mathrm{kg}$ while sub-chronic toxicity showed a significant decrease $(\mathrm{p}<0.05)$ in serum liver enzymes activities (AST and ALT), serum concentration of total protein, urea, $\mathrm{K}^{+}$, and creatinine with significant increase $(\mathrm{p}<0.05)$ in ALP activity and serum concentrations of $\mathrm{Na}^{+}, \mathrm{Cl}^{-}$, and $\mathrm{HCO}^{-}$in groups II to IV in dose dependent pattern compared to the normal control. Therefore, findings showed that there are no toxic effects of ASENS on rat's liver and kidneys functions indices as evidence by biochemical parameters and also it's relatively safe at administered doses.
\end{abstract}

Keywords: Nigella sativa, acute toxicity, Sub-chronic toxicity and seed extract.

DOI: $10.7176 / \mathrm{FSQM} / 102-06$

Publication date: November $30^{\text {th }} 2020$

\section{Introduction}

Medicinal plants have been used for curing diseases for many centuries in different indigenous systems of medicine as well as folk medicines. Moreover, medicinal plants are also used in the preparation of herbal medicines as they are considered to be safe as compared to modern allopathic medicines. The World Health Organization has depicted that about $60 \%$ of the world's population rely on traditional medicine, and $80 \%$ of the population in developing countries depend almost completely on traditional medical practices for their primary health care (WHO, 2001). Many researchers are focusing on medicinal plants because only a few plant species have been thoroughly investigated for their medicinal properties, mechanism of action, safety evaluation and toxicological studies.

However, a great number of plants in Nigeria are noted traditionally for their medicinal properties, but only few have so far been studied for their active constituents, some plant extracts could be inherently dangerous, containing naturally occurring toxins, which may be cytotoxic or carcinogenic (Humphrey and McKenna, 1997). However, among various medicinal plants, Nigella sativa (black seed) has been used as herbal medicine for more than 2000 years (El-Dakhakhny et al., 2000). It is also used as a food additive and flavoring agent in many countries (Anwar, 2005). N. sativa is native to Southern Europe, North Africa, Southwest Asia and it's cultivated in many countries in the world like Middle Eastern Mediterranean region, South Europe, India, Pakistan, Syria, Turkey and Saudi Arabia (Khare et al., 2005). Recently, clinical and animal studies have shown that extract of the black seeds have many therapeutic effects (Babazadeh et al., 2012).

Furthermore, according to Anwar (2005), many studies have been conducted on the Nigella sativa but only few are concerned about its toxicity. Therefore, this study was to evaluate Phytochemical composition, determining $\mathrm{LD}_{50}$ and sub-chronic toxicity studies of the methanol seeds extract of Nigella sativa in albino rats as the plant is widely used in traditional medicine.

\section{Methodology}

\subsection{Collection and Extraction of Plant Material}

Nigella sativa seeds powder was bought from Sabon Gari Market, Kano state, Nigeria. The powder (300g) was weighed and soaked in $1.5 \mathrm{~L}$ of methanol overnight, filtered and the solvent was evaporated. The solid extract obtained was reconstituted and the volume administered to each rat was calculated according to (Muhammad et al., 2016).

\subsection{Phytochemical Screening}

Phytochemical tests were carried out by using the standard methods of Sofowora (1993), Parekh and Chanda 
(2007), Trease and Evans (1989) and El- Olemyl et al (1994).

\subsection{Experimental Animals}

Twenty five albino rats of both sexes (weighing 100-150g), were obtained from Department of Biological Science, Bayero University Kano, Nigeria. They were kept, at room temperature, in wire-mesh cages. The animals were had feed with standard palletized grower feed and drinking water and the experiments was performed according to the principles of laboratory animal care.

\section{4. $L D_{50}$ Determination}

The $\mathrm{LD}_{50}$ was determined using (Lorke, 1983). Nine rats were used in the first phase (phase I), the rats were divided into three groups of three rats each. They were administered with ASENS at doses of 10,100 and $1000 \mathrm{mg} / \mathrm{kg}$ orally. The administered rats were monitored $24 \mathrm{hrs}$, for mortality and general behavior. In second phase (phase II), four rats were used and grouped into four groups of single rat each and they were administered with ASENS at doses of $1500,2500,3500,5000 \mathrm{mg} / \mathrm{kg}$ orally and were observed for mortality and other signs of toxicity for $24 \mathrm{hrs}$.

\subsection{Sub-chronic Toxicity Studies}

Twelve rats were divided into four groups of three rats each. The extract was administered orally to the rats in groups II to IV at doses of $10 \mathrm{mg} / \mathrm{kg}, 100 \mathrm{mg} / \mathrm{kg}$ and $1000 \mathrm{mg} / \mathrm{kg}$ body weight respectively. Group I rats served as control and they were given an equivalent volume of normal saline orally under the same conditions. All the rats were sacrificed after 28 days of extract administration. Blood samples were collected for biochemical analysis.

\subsection{Statistical Analysis}

Results were expressed as mean \pm standard deviation. The data collected were subjected to one-way Analysis of Variance (ANOVA) using Graphad Instat, Version 3.02, Benferoni, (San Diego, USA) (GraphPad, 2000).

\section{Results}

\subsection{Phytochemical screening}

The results of the qualitative and quantitative phytochemical screening of methanol seeds extract of Nigella sativa are presented in Table 1. Results of qualitative analysis indicated the presence of alkaloids, flavonoids, glycoside, saponin, tannins and terpenoids while quantitative analysis shows that the extract is rich in glycosides $(2.839 \mathrm{~g})$, flavonoids $(1.442 \mathrm{~g})$, alkaloids $(0.358 \mathrm{~g})$, saponin $(0.330 \mathrm{~g})$, tannins $(0.058 \mathrm{~g})$ and low quantity of terpenoids $(0.043 \mathrm{~g})$.

Table 1: Phytochemical screening of the methanol seeds extract of Nigella sativa

\begin{tabular}{llc}
\hline Phytochemical constituents & Inference & Content $(\mathrm{g} \%)$ \\
\hline Alkaloids & + & $0.358 \pm 0.35$ \\
Anthraquinone & - & - \\
Flavanoids & + & $1.442 \pm 0.02$ \\
Glycosides & + & $2.839 \pm 0.01$ \\
Saponin & + & $0.330 \pm 0.01$ \\
Steroids & - & - \\
Tannins & + & $0.058 \pm 0.06$ \\
Terpenoids & + & $0.043 \pm 0.04$ \\
\hline
\end{tabular}

Key; (+) means present, (-) means not detected

\subsection{Acute toxicity studies}

In both phases no signs of toxicity or mortality were observed at the doses up to $5000 \mathrm{mg} / \mathrm{kg}$ for 48 hours of the extract administration.

Table 2: Phase I LD 50 , (Oral, rat) of the methanol seeds extract of Nigella sativa

\begin{tabular}{ll}
\hline Doses $(\mathrm{mg} / \mathrm{kg})$ & Result \\
\hline 10 & $0 / 3$ \\
100 & $0 / 3$ \\
1000 & $0 / 3$ \\
\hline
\end{tabular}


Table 3: Phase II LD ${ }_{50}$, (Oral, rat) of the methanol seeds extract of Nigella sativa

\begin{tabular}{ll}
\hline Doses $(\mathrm{mg} / \mathrm{kg})$ & Result \\
\hline 1500 & $0 / 1$ \\
2500 & $0 / 1$ \\
3500 & $0 / 1$ \\
5000 & $0 / 1$ \\
\hline
\end{tabular}

\subsection{Sub-chronic Toxicity Studies}

The effect of ASENS on kidney function indices, serum liver enzymes activities (AST, ALT and ALP) and serum albumin, Bilirubin and total protein concentrations in rats that were administered orally at doses of 10,100 and $1000 \mathrm{mg} / \mathrm{kg}$ after 4 weeks is shown below. A significant decrease in the serum AST, ALT and Albumin, total protein level $(p<0.05)$ in groups II, III and IV with significant increase $(p>0.05)$ in serum ALP concentration observed compared with normal control, while total and direct Bilirubin levels were not significant. Also, a significant decrease $(\mathrm{p}<0.05)$ in the serum Urea, Potassium $\left(\mathrm{K}^{+}\right)$and Creatinine levels in groups II, III and IV with significant increase $(\mathrm{p}<0.05)$ in serum Sodium $\left(\mathrm{Na}^{+}\right)$, Chloride $\left(\mathrm{Cl}^{-}\right)$and bicarbonate $\left(\mathrm{HCO}_{3}{ }^{-}\right)$levels observed compared with normal control.

Table 4: Serum liver enzymes activities and serum concentrations of ALB, DB and TB and TP in rats after 4 weeks oral administration of ASENS

\begin{tabular}{llllllll}
\hline Group & \multicolumn{1}{c}{ AST(U/L) } & ALT(U/L) & ALP(U/L) & ALB $(\mathrm{g} / \mathrm{dl})$ & $\mathrm{DB}(\mathrm{mg} / \mathrm{dl})$ & $\mathrm{TB}(\mathrm{mg} / \mathrm{dl})$ & $\mathrm{TP}(\mathrm{g} / \mathrm{dl})$ \\
\hline I & $34.33 \pm 2.88^{\mathrm{a}, \mathrm{b}, \mathrm{c}}$ & $27.67 \pm 2.31^{\mathrm{a}, \mathrm{b}, \mathrm{c}}$ & $57.21 \pm 3.36^{\mathrm{a}, \mathrm{b}}$ & $6.42 \pm 0.3^{\mathrm{a}}$ & $0.30 \pm 0.0$ & $1.64 \pm 0.07^{\mathrm{d}}$ & $9.64 \pm 40.2^{\mathrm{a}, \mathrm{b}}$ \\
II & $30.76 \pm 1.64^{\mathrm{a}}$ & $22.67 \pm 2.52^{\mathrm{a}}$ & $59.95 \pm 1.47$ & $5.10 \pm 0.55$ & $1.20 \pm 0.10$ & $1.28 \pm 0.53^{\mathrm{h}}$ & $8.76 \pm 0.76$ \\
III & $25.43 \pm 2.94^{\mathrm{b}}$ & $19.33 \pm 6.66^{\mathrm{b}}$ & $66.71 \pm 9.47^{\mathrm{a}}$ & $5.06 \pm 1.32$ & $1.22 \pm 0.83$ & $1.78 \pm 0.06^{\mathrm{i}}$ & $6.95 \pm 7.74^{\mathrm{a}}$ \\
IV & $19.28 \pm 2.38^{\mathrm{c}}$ & $13.79 \pm 4.68^{\mathrm{c}}$ & $69.27 \pm 2.88^{\mathrm{b}}$ & $4.84 \pm 1.05^{\mathrm{a}}$ & $1.73 \pm 1.65$ & $2.64 \pm 0.12^{\mathrm{d}, \mathrm{h}, \mathrm{I}}$ & $4.36 \pm 6.42^{\mathrm{b}}$
\end{tabular}

Values are presented as mean $\pm \mathrm{SD}, \mathrm{n}=3$. Values with similar superscript on the same column are significant $(\mathrm{p}<0.05)$. Key: $\mathrm{AST}=$ Aspartate amino Transferase, $\mathrm{ALP}=$ Alkaline phosphatase, ALT $=$ Alanine amino Transferase, $\mathrm{TB}=$ Total Bilirubin, $\mathrm{ALB}=$ Albumin, $\mathrm{TP}=$ Total protein.

Table 5: Serum Urea, Creatinine and electrolytes levels in rats after four weeks oral administration of ASENS.

\begin{tabular}{lcccccc}
\hline Group & Urea $(\mathrm{mg} / \mathrm{dl})$ & $\mathrm{Na}^{+}(\mathrm{mmol} / \mathrm{L})$ & $\mathrm{K}^{+}(\mathrm{mmol} / \mathrm{L})$ & $\mathrm{Cl}^{-}(\mathrm{mmol} / \mathrm{L})$ & $\mathrm{HCO}_{3}{ }^{-}(\mathrm{mmol} / \mathrm{L})$ & Creatinine $(\mu \mathrm{mol} / \mathrm{L})$ \\
\hline I & $44.42 \pm 4.03^{1, \mathrm{k}, \mathrm{m}}$ & $135.75 \pm 7.82^{\mathrm{m}, \mathrm{n}}$ & $3.37 \pm 0.11^{\mathrm{p}, \mathrm{q}}$ & $56.09 \pm 4.87^{\mathrm{r}, \mathrm{s}, \mathrm{t}}$ & $24.72 \pm 3.32^{\mathrm{u}, \mathrm{v}, \mathrm{w}}$ & $46.00 \pm 0.01^{\mathrm{x}, \mathrm{y}, \mathrm{z}}$ \\
II & $41.06 \pm 1.16^{1}$ & $137.29 \pm 5.07$ & $3.12 \pm 0.05$ & $59.35 \pm 1.41^{\mathrm{r}}$ & $27.49 \pm 6.92^{\mathrm{u}}$ & $38.33 \pm 0.27^{\mathrm{x}}$ \\
III & $30.29 \pm 2.02^{\mathrm{k}}$ & $152.55 \pm 2.54^{\mathrm{m}}$ & $2.42 \pm 0.45^{\mathrm{p}}$ & $69.10 \pm 3.07^{\mathrm{s}}$ & $50.48 \pm 10.36^{\mathrm{v}}$ & $25.45 \pm 2.13^{\mathrm{y}}$ \\
IV & $22.21 \pm 2.02^{\mathrm{m}}$ & $169.58 \pm 3.76^{\mathrm{n}}$ & $2.04 \pm 0.06^{\mathrm{q}}$ & $79.67 \pm 3.73^{\mathrm{t}}$ & $55.80 \pm 4.81^{\mathrm{w}}$ & $20.62 \pm 2.55^{\mathrm{z}}$ \\
\hline
\end{tabular}

Values are expressed as mean $\pm \mathrm{SD}, \mathrm{n}=3$. Values with similar superscript on the same column are significant $(\mathrm{p}<0.05)$. Key: $\mathrm{K}^{+}=$Potassium, $\mathrm{Cl}^{-}=$Chloride, $\mathrm{Na}^{+}=$Sodium, $\mathrm{HCO}_{3}{ }^{-}=$Bicarbonate .

\section{Discussion}

The results obtained after qualitative phytochemical screening of the ASENS indicated the presence of flavonoids, alkaloids, cardiac glycosides, saponins, tannins and terpenoids. The quantitative phytochemical screening shows a high concentration of glycosides followed by flavonoids, alkaloids, saponins, tannins and then terpenoids. These results agree with the findings of A1-Yahya (1986) who also reported the presence of the above phytochemicals in Nigella sativa. Phytochemical have been reported to have medicinal uses. Phytochemical components such as Flavonoids, tannins, alkaloids and terpenoids are responsible for various pharmacological activities of the plants (Shah et al., 2011). These phytochemical compounds are synthesized by primary or secondary metabolism of living organisms. Secondary metabolites are taxonomically and chemically diverse compounds with huge function which are extensively used in agriculture, human therapy, veterinary and related scientific research (Mansoor et al., 2011).

Also, the results of $\mathrm{LD}_{50}$ studies does not show any sign of toxicity or mortality up to a higher dose of $5000 \mathrm{mg} / \mathrm{kg}$. This agrees with the findings of Bouguezza et al (2013). who reported up to $5 \mathrm{~g} / \mathrm{kg}$ body weight orally of methanolic extract in mice. The result of the acute toxicity study indicated that the plant is practically non-toxic and can be used for many therapeutic purposes.

Sub-chronic studies reveal the extract to be harmless to the liver. These results are in agreement with the work of Mohammad (2010) which showed that oral administration of aqueous extract of Nigella sativa seeds did not bring significant changes in liver function indices. Another studies, reported no toxic effects of Nigella sativa on hepatic enzymes among asthmatic patients while another studies failed to show any toxicity for Nigella sativa fixed oil in mice (Al-Ghamdi, 2003).

Furthermore, the reduction in levels of serum $\mathrm{K}^{+}$, Urea and Creatinine in extract administered was supported by the study of Le et al (2004) in normal rats administered with petroleum ether extract of $N$. sativa for four weeks. 
This study shows that administration of ASENS for four weeks did not change the biochemical parameters of kidney function indices and in relation to this findings, it was previously reported that administration of $N$. sativa showed no significant changes in kidney function (Ali and Blundes, 2003).

\section{Conclusion}

The study showed that Nigella sativa methanol seeds extract possess various phytochemicals which may be responsible for the reported pharmacological activities of the plant. Toxicological studies shows the extract to be practically non-toxic up to dose of $5000 \mathrm{mg} / \mathrm{kg}$ in terms of $\mathrm{LD}_{50}$, with no toxic effects on liver and kidney functions indices after four weeks of administration and it may be considered safe at the tested doses.

\section{References}

A1-Yahya, M., A. (1986). Phytochemical studies of the plants used in traditional medicine of Saudi Arabia. Fitoterapia. 1986; 57(3): 179-182.

Al-Ghamdi, M., S. (2003). Protective effect of Nigella sativa seeds against carbon tetrachloride-induced liver damage, Am J Chin Med., 31(5), 721-728.

Ali, B., H., Blundes, G. (2003). Pharmacological and toxicological properties of Nigella sativa. Phytother Res.; 17(4): 299-305.

Anwar, M., A. (2005). Nigella sativa: A bibliometric study of the literature on Habbatul-Barakah. Malays J Libr \& Inf Sci. 10(1):1-18.

Babazadeh, B., Sadeghnia, H., R., Safarpour-Kapurchal, E., Parsaee, H., Nasri, S., and Tayarani-Najaran, Z.(2012).Protective effect of Nigella sativa and thymoquinone on serum/glucose deprivation-induced DNA damage in PC12 cells, Avicenna J Phytomed., 2: 125-132.

Bouguezza, Yacine, Bribi, Noureddine, Tacherfiout, Mustapha, Amara, Samira, Khettal, and Bachra (2013). Acute and subchronic toxicity study of Nigella Damascena methanolic seed extract in mice. Int j pharm bio sci., 4(2): Pp 413- 419.

Cheikh-Rouhou, S., Besbes, S., Hentati, B., Blecker, C., Deroanne, C., and Attia, H. (2007). Nigella sativa L.: Chemical composition and physicochemical characteristics of lipid fraction. Food Chem.; 101: 673-681

El-Dakhakhny, M., Barakat, M., and El-Halim, M., A. (2000).Effect of Nigella sativa oil on gastric secretion and ethnol-induced ulcer in rats. $J$ Ethnopharmacol. 72: 299-304.

El-Olemy, M., M., Al-muhdtadi, F., J., and Afifi, A., A. (1994). Experimental Phytochemistry. A laboratory manual. Published by King Saudi University Prees $5^{\text {th }}$ ed. Pp 247.

GraphPad Instat3 Software (2000). Available: www.graphpad.com. Retrieve on 23rd February 2017.

Humphrey, S.I. and McKenna, D.J. (1997). Herbs and breastfeeding. Breast feeding Abstracts, 17: 11-12.

Khare, P., C., Yelne, M., B., Dennis, T., J. (2005).Database on medicinal plants used in Ayurveda. New Delhi. pp. 420-440.

Le, P., M., Benhaddou, A., A., Settaf, A., Cherrah, Y., Haddad, P., S. (2004). The petroleum ether extract of Nigella sativa exerts lipid lowering action in the rats. $J$ Ethanopharmacol. 94:251-259.

Lorke, D. (1983). A New approach to practical acute toxicity testing. Arch. toxicol. 53:275-287

Mansoor, A., Ibrahim, M., A., Zaidi, M., A., Ahmed, M. (2011). Antiprotozoal activities of Carum copticum Bangl. $J$ Pharmacol.; 6:51-54

Mohammad, A., K. (2010). Ameliorative effect of black seed (Nigella sativa L) on the toxicity of aluminum in rabbits. Iraqi J vet Med., 34(2):110-6.

Muhammad I. U., Alhassan A. J., Sule M. S., Idi A., Mohammed A., El- ta'alu A. B., Dangambo M. A. and Abdulmumin Y. (2016). Anti- Hyperglycemic Activity of Solvents Extract of Khaya senegalensis Stem Bark in Alloxan Induced Diabetic Rats. Journal of Advances in Biology \& Biotechnology 6(2): 1-8

Parekh, J., and Chanda, S., U. (2007). In- vitro antimicrobial activity and phytochemical analysis of some Indian medicinal plants. Turk J Biol. 31:53-58

Shah, A., J., Zaidi, M., A., Sajjad, H., Hamdullah, Gilani, A., H. (2011). Antidiarrheal and Antispasmodic activities of the extract of Vincetoxicum stocksii are mediated through calcium channel blockade. Bangl J Pharmacol.; 6:46-50.

Sofowora, A. (1993). Medicinal Plants and Medicine in Afric.John Willey Spectrum, Ibadan-Nigeria. Pp. 2, 81 85

Trease, G.E. and Evans, W.C. (1989). Pharmacognosy. A physician guide to herbal medicine, 11edn. Ballere Tindal, London, UK, pp 530.

WHO (2001). Legal status of Traditional Medicines and Complementary/ Alternative Medicine. A worldwide review. WHO publishing1. 